\title{
State of Exception: The Birthplace of Kafka's Narrative Authority
}

Vladimir Biti

Institute of Slavic Studies, University of Vienna, Spitalgasse 2 / Hof 3, 1080 Vienna, Austria https://orcid.org/0000-0001-8873-0339

vladimir.biti@univie.ac.at

Across the postimperial East Central Europe, whose geopolitical space was reconfigured on the model of West European nation-states, unprocessed human residues proliferated as the collateral effects of politically guided national homogenizations. These positional outsiders, who were prevented from becoming legible within the newly established political spaces, take center stage in Kafka's narratives, not only in the form of their characters but also their narrators and ultimate authority. They passionately attach themselves to the zones of indistinction, which the modern societies' 'egalitarian discrimination' has doomed them to, thus trying to turn their enforced dispossession into a chosen self-dispossession. I argue that Kafka's narratives owe their elusive ultimate authority precisely to this persistent translation of the political state of exception of his agencies into their literary state of exemption. They are at constant pains to transfigure the imposed state of exception through its peculiar fictional adoption, but Kafka's ultimate narrative authority nevertheless takes care to keep an edge over their efforts. It is precisely this never-ending gradation of subversive mimicry in Kafka's works that his postcolonial successor J. M. Coetzee most admired.

Keywords: Austria-Hungary / Central European literature / literary periphery / Kafka, Franz / literary characters / outsiders / subversivity

Barely a year after the death of Emperor Franz Joseph, ${ }^{1}$ Franz Kafka worked on "At the Construction of the Great Wall of China," which, from the perspective of an anonymous stonemason, focuses on the unification of the Chinese Empire out of seven warring states. The huge geopolitical and historical dislocation of the transfiguring empire- transposed from East Central Europe at the outset of the twen-

${ }^{1}$ Vladimir Biti is currently Distinguished Chair Visiting Professor at Guangdong University of Foreign Studies and Zhejiang University.

${ }^{2}$ Willa and Edwin Muir translate "Beim Bau der chinesischen Mauer" as "The Great Wall of China," thus bereaving the title of the concepts "at" and "construction" that are, as I will show, extremely important. 
tieth century to ancient China-engenders a kind of parable, Kafka's favorite literary genre. Parables are, by definition, narrated by slaves or underdogs. ${ }^{3}$ To underline the insignificance of its narrator, the parable's first part merges him into a "we" of manual laborers, doomed to observe the construction from the confined point of view of its "most miserable" subjects (jämmerlichste Untertanen, Beim Bau 75, trans. modified). ${ }^{4}$ In fact, the stonemason submits his report after the Great Wall of China had already been completed, thus benefiting from a retroactive insight. During the construction, he and his companions were confined to a particular part of the wall that they were appointed to build and were thus bereft of the general view that was reserved for experts and supervisors.

According to the official proclamation, the wall was erected to protect China from an invasion by northern tribes but, fragmentary as it was, it could not really offer protection from those who, due to their nomadic mobility, better understood its flaws than the workers themselves. Nevertheless, the narrator realizes, the system of piecemeal building was deliberately chosen, carefully prepared, and superbly carried out by "the high command" (The Great Wall 271). What this supreme agency was aiming for was a unity of the Empire distilled out of its enormous diversity:

Groups of people with banners and streamers waving were on all the roads; never before had they seen how great and rich and beautiful and worthy of love their country was. Every fellow countryman was a brother for whom one was building a wall of protection, and who would return lifelong thanks for it with all he had and did. Unity! Unity! Shoulder to shoulder, a ring of brothers, a current of blood no longer confined within the narrow circulation of one body, but sweetly rolling and yet ever returning throughout the endless leagues of China. (269)

Thus, ultimately, it was neither the Huns nor the Emperor's decree that triggered the wall-building, but the high command's conviction in the

${ }^{3}$ Hegel compares them to fables (Hegel 391), the subordinate narrators of which do not dare to transmit their "doctrines openly but can only make them understood hidden [...] In the slave, prose begins, and so this entire genre is prosaic" (387).

${ }^{4}$ Next to this parable, the narrative perspective that switches between the "we" and "I" characterizes some of Kafka's other narratives as well, such as "The Refusal" or "Josephine the Singer." In the German critical edition of 1994, which is my departure point, the concluding part of "At the Construction" is narrated from the "I" perspective. In the American edition of The Collected Stories (1971), this part is published separately under the title "The News of the Building of the Wall: A Fragment" (280-282). 
necessity of uniting diversity. The narrator pays considerable attention to this political background of the seemingly illogical system of piecemeal construction. He claims that a far-reaching recalibration of the imperial common-being was envisaged through the central assignment of various groups' respective tasks. This is "one of the crucial problems in the whole building of the wall" that he "cannot go deeply enough into" (270). His scholarly focus and discourse remind us that the mask of a humble stonemason, in accordance with the genre's ventriloquist rule, is in fact worn by an interested and attentive explorer.

For readers during Kafka's time, an analogy with the Dual Monarchy's political reconfiguration after the defeat at Königgrätz in 1866 was undoubtedly at play. In the last decades of the nineteenth century, the frustrated Empire not only reoriented its agenda toward the Slavic population of eastern and southeastern Europe but also translated it from conquering and assimilating into civilizing and affirming terms. No longer denied, the inferior others were now acknowledged in their particularity. Accordingly, the aim of cosmopolitan projects like the Vienna World's Fair (1873) or the encyclopedia Die österreichischungarische Monarchie in Wort und Bild (1885-1907) was to establish the monarchy's unity-in-diversity (Judson 317-328). However, as in the Chinese case, the envisioned homogenization merely reaffirmed the gap between the center and its peripheries. Since the Slavs were taken as still living in the mythic phase of human history, they were expected to help the Germans, as the carriers of historical progress, rejuvenate themselves.

Through the centrally governed project of unity-in-diversity, the domination of German culture over its peripheral Slavic constituencies was thus maintained. The expansion of the traffic and communicational infrastructures, as well as the administrative and educational networks, into the Slavic regions strengthened the interaction between governmental institutions and these peripheral collectivities but came at the price of loosening connections between themselves. Governments' insistences on their belonging to a particular ethnic group (Anderson 162-185; Stourzh 81) compartmentalized the imperial population, encapsulating its collectivities into their allocated identity confines. This is how the subdividing mechanisms of 'capillary supervision' entered the Habsburg political space, paving the way for its transformation along national lines (Judson 317-328; Cohen 2013).

Analyzing this restructuring of imperial common-being in his Discipline and Punish, Foucault draws an analogy with Jeremy Bentham's penitentiary Panopticon: 
Each individual, in his place, is securely confined to a cell from which he is seen from the front by the supervisor; but the side wall prevents him from coming into contact with his companions. He is seen, but he does not see; he is the object of information, never a subject in communication. The arrangement of his room, opposite the central tower, imposes on him an axial visibility; but the divisions of the ring, those separated cells, imply a lateral invisibility. And this invisibility is a guarantee of order. "[...] The crowd [...] is abolished and replaced by a collection of separated individualities. From the point of view of the guardian, it is replaced by a multiplicity that can be numbered and supervised; from the point of view of the inmates, by a sequestered and observed solitude. (200-201)

Since in the center "one sees everything without ever be seen" and in the peripheries "one is totally seen, without ever seeing" (202), control over the population is accomplished without the public manifestations of power that were characteristic of the previous age of sovereignty. Now the power throws off its corporeality, becoming an anonymous machine with myriad operators, rendering its ultimate agency unverifiable. Its multiplied relays reproduce the power relation by themselves, without any identifiable external force.

By pointing out that "no one whom I have asked knew then or knows now [where] the office [of the high command] was and who sat there" (The Great Wall 271), Kafka's narrator addresses precisely this withdrawal of the ultimate authority from historical evidence. The high command was not a hastily summoned body of mandarins but "has existed from all eternity, and the decision to build the wall likewise" (273). As the current leaders "traced their plans," through the window of their office "the reflected splendors of divine worlds fell" on their hands (271). This vanishing of the supreme authority into the divine sphere renders it impenetrable for the common people. Around it, the "fog of confusion" (274) grows. Even though the common people are entitled to know it, it is stranger to them than the "life beyond" (das jenseitige Leben). ${ }^{5}$ Its obscurity exposes them to an enduring uncertainty and discontent.

Kafka was deeply concerned about the consequences of the delineated exception of the law from the realm of those governed by it. Cautioned by the same developments, his contemporary Carl Schmitt notices that, in the recent state of exception, the law only belongs to the juridical order by occupying a constitutively external position within it (Schmitt 7; Agamben 2, 35). In “The Problem of Our Laws," Kafka's

\footnotetext{
${ }^{5}$ Muirs translate "life beyond" as "the next world" (278).
} 
narrator states "it is an extremely painful thing to be ruled by laws that one does not know" (The Problem 482). When he further remarks that "the laws were made to the advantage of the nobles" who stand above them (482), he again anticipates Foucault's insight that disciplinary power, praised for its egalitarianism, in fact establishes "the inequality of the different "partners" "in relation to the common regulation" (Foucault 223). Having "the precise role of introducing insuperable asymmetries" (222), it reaffirms the basic power relation between the law that comprehends all its subjects and those whose comprehension it escapes. Taking the shape of an appearance 'from beyond,' it remains an enduring mystery (The Problem 482) whose dictum has to be detected by each subject individually, with all the risk of invention that this implies. Since in the disciplinary society, "between the [juridical] norm and its application there is no internal nexus that allows one to be derived immediately from the other" (Agamben 40), Agamben interprets this derivation as controversial and conflict-ridden, involving a "plurality of subjects" (39-40). As if illustrating Agamben's insight into the modern law's dissensual pluralization much in advance, Kafka concludes "The Problem of Our Laws" by presenting a conflict of its interpretations bereft of resolution.

The further the law reaches on its way to the periphery, the less trust it evokes in its addressees. Instead of feeling protected, they feel victimized by it. In "The Refusal," a report from a remote, imperial "little town" in the middle of nowhere, the local narrator (again a wolf in sheep's clothing) offers the portrait of a "chief tax-collector," the imperial administration's representative in this godforsaken province. He is an "old man" who "commands the town" although he never "produced a document entitling him to his position; very likely he does not possess such a thing. Maybe he really is chief tax-collector" (The Refusal 296).

But is that all? Does this entitle him to rule over all the other departments in the administration as well? True, his office is very important for the government, but for the citizens it is hardly the most important. One is almost under the impression that the people here say: "Now that you've taken all we possess, please take us as well." (296-297)

If we now return to The Great Wall, when the stonemason first learned of the Emperor's decision to build the wall — thirty years after it was publicly announced-he was a small boy accompanying his father on a walk along the river (Beim Bau 79). Approaching his father, an unknown boatman whispered the message in his ear, meeting his deepest mistrust. Like many of Kafka's unfinished works that went unpublished 
during his lifetime, the parable is interrupted here. Its only published fragment, focusing on the failed transfer of law to the peripheries, is the embedded parable "An Imperial Message". In a manner illustrated in his aphorism "On parables," Kafka lures his reader into taking this embedded parable as a key for the parable which hosts it. In fact, the transfer of trust between parables, like the transfer of law from the Emperor to his subjects, cannot but fail by requiring further transfers to make up for the failure.

Significantly, "An Imperial Message" opens with the same act of entrusting a humble peripheral subject that closes "The Great Wall of China," albeit now from the Emperor's perspective instead of that of his remote addressee. Passing away, the Emperor addresses precisely this "miserable subject, the insignificant shadow" in the uttermost imperial province by ignoring all "the great princes of the Empire" who had assembled to witness the spectacle of his death (The Great Wall 275 , trans. modified). In lieu of approaching the attending nobility, in accordance with the centuries-long tradition of public spectacles, he entrusts his last will to the messenger whom he commanded "to kneel down by the bed, and whispered the message to him; so much store did he lay on it that he ordered the messenger to whisper it back into his ear again" (275). Thus, obviously concerned with the rising mistrust of his peripheral subjects that threatens the maintenance of the empire, ${ }^{6}$ he switches from the public visual demonstration of his will to the assembled princes to its private oral transmission to anonymous peripheral subjects. Choosing a method of its delivery right into the ear of his messenger, whom he expects to dispatch its exact rendering door to door, the Emperor introduces the new "capillary supervision" of all his subjects. Nonetheless, the narrator argues, his replacing of the amorphous crowd by a "collection of separated individuals" (Foucault 201) fails to consolidate the endangered imperial common-being because the privately entrusted law loses transparency and becomes elusive. Internally processed by myriad addressees, it dissolves into an "imaginary norm" (Slaughter 215) that is wholly dependent on the interpretation of the individuals who apply it and therefore completely arbitrary.

Kafka's heroes and narrators are turned into the helpless targets of this fictional law that looms large on the horizon of his time. In The Trial, for example, its operators prove to be extremely whimsical.

${ }^{6}$ The last sentence of the "News of the Building of the Wall" reads: "For it seems that infidel tribes, among them demons, often assemble before the imperial palace and shoot their black arrows at the Emperor" (281). 
In fact, this title, which associates a public dispute in the courtroom, mistranslates the German Der Proce $\beta$ that refers to a preliminary and, by definition, secret process of examination (Ziolkowski 226). Rather than the written law, it relies upon its representatives' contingent performances that pretend to be authorized but cannot prove this due to the "high command's" inaccessibility. Such circumstances make legislation tantamount to its random execution (Friedman, Bergengruen). It is telling that the guards appointed to arrest Josef $\mathrm{K}$. carry the names of the Austrian and German emperors of the time: Franz and Willem. Delivered to the self-willingness of such petty sovereigns, he is relegated to a "zone of indistinction" deprived of legal rights. While in the simultaneously composed story "In the Penal Colony," Kafka openly confronts the European allegedly liberal legal system with the summary justice of its penal colony, in this novel the legal system is invisibly perverted by the summary justice from within. Aberrations do not threaten it from outside, but are from the very beginning its constitutive parts. As Foucault spelled out half a century later, within one and the same modern juridical frame, the capillary mechanisms of counter-law disqualify and invalidate the egalitarian law by turning it into a discriminatory inquisitorial machine (Foucault 222-227).

Doomed to this frame's devastating effects, Kafka's subjects experience it out of its lawless "heterotopias" proliferating across its expanding network. Thus, epitomizing the Austro-Hungarian juridical system of the time, entirely focused on "inventing the criminal" (Wetzel), the magistrates examine Josef K.'s presumed criminal motivation rather than any verifiable crime. When he refuses to accept such martial law as the necessary "order of the world" (Der Proceß 233), he speaks for all outsiders who, like the narrators of "The Great Wall of China" and "The Problem of Our Laws," tend to dismantle its utter fictionality and randomness. Paradoxically, to turn their passive location of the targeted "objects of information" into the active position of the targeting "subjects in communication" (Foucault 200), they engage the same maneuver of self-exemption, which their executors take advantage of while imposing the law upon them. While the executors exempt themselves from the law which they apply to others, the outsiders exempt themselves from its undertaken application. Whereas the executives are at pains to exactly locate the law's subjects, the outsiders invest their efforts to limit the locating capacity of its executives. In response to the executives' silent message that we can formulate as "Examine our law as much you like, it is beyond the location that it has assigned you!", they claim something like "Our extreme dislocation places us beyond 
the reach of your law!". To limit the power of the executives who are in charge of them, Kafka's appointed outsiders, as it were, adhere to Wittgenstein's dictum: "Distrust of grammar is the first requisite for philosophizing" (Wittgenstein 106). Rather than obeying this legal "grammar" that turns them into its outsiders, they attach their imagination to its suppressed possibilities, as if following Lucy's advice from J. M. Coetzee's Disgrace: "When all else fails, philosophize" (Disgrace 60). In this manner they transform their restricted location into a much more mobile room for maneuver. Consider Josef K.'s insight on the very eve of his execution: "Were there objections that had been forgotten? There must have been some. The logic is irrefutable, but it cannot resist someone who wants to live" (Der Proceß241).

The suppressed possibilities of the reigning "grammar" figure as the source of authorization not only for Kafka's protagonists, but also for his narrators who make even more extensive use of them. Thus, at the beginning of "An Imperial Message," the narrator operates as a humble relay of its historical transmittance ear to ear, a technique introduced by the Emperor, via his messenger, many centuries ago. However, if the parable was transmitted to him in this oral manner-as testified by "it is said" at its very beginning-from now on it acquires written form that enables it to directly address its distant trustee, the reader. By apostrophizing him or her through the immediate "you alone," the narrator heightens the efficiency of the emperor's formerly mediate address. What was mediated through the messenger in the imperial oral form becomes immediate in the modern written form. Activating the potential of the new medium that bridges both spatial and temporal distances much easier, the initially insignificant narrator of "An Imperial Message" suddenly acquires "imperial" abilities. He now manages the emperor as his character instead of the other way around. As a result, while the report of the narrator of "The Great Wall of China" encompasses no less than three centuries from the first announcement to the eventual completion of its construction, his own report covers "thousands of years" of the message's failed transmission. Both narrators turn from riveted subhuman creatures into the mobile superhuman observers in possession of sovereign insight.

To uncover the ultimate agency of such a subterraneous entitlement of theirs, we have to recall Kafka's diary entry of 28 September 1917:

I strive to know the whole human and animal community, to recognize their basic predilections, desires, moral ideals, to reduce these to simple rules and as quickly as possible trim my behavior to these rules in order that I may find favor in the whole world's eyes [...] To sum up, then, my sole concern is the 
human tribunal, which I wish to deceive, moreover, though without practicing any actual deception. (Diaries 387)

Instead, he practices an imaginary self-exemption from the restricted historical world of humans into the inexhaustible potentiality of life. Therefore, whenever Kafka's figures and narrators lay claim to this 'state of exception,' they act as the appointed and carefully supervised messengers of his withdrawn authorial agency. Foreshadowing his great admirer J. M. Coetzee, an inhabitant of another postimperial state of exception, Kafka's authorial agency operates as the chief "secretary of the invisible". ${ }^{7}$ His narratives are constructed in the piecemeal manner of the Great Wall of China: the fragments of the upcoming redemption as distributed by the "high command's" limitless possibilities. The "high command," in its turn, remains invisible and inaccessible.

In a letter to Max Brod from November 1917 Kafka expressed his hope that, in a time yet-to-come, "a whole will be made up of these bits" to serve (their readers) as "an instance of appeal" (Briefe 195). Up to then, as announced by the title "At the Construction," the work of scattered construction must persevere. Like the presumptive mole from "The Burrow" (the original German title reads, literally, "The Construction"), ${ }^{8}$ Kafka's author is persistently at the construction, involved in an enterprise-in-making. In the state of exception which makes anything possible, the ongoing destruction of the political common-being does not permit its aesthetic completion. As Coetzee points out in his reading of Kafka's last narrative, nothing can protect its law from the intrusion of a counter-law that perverts it ("Time, Tense, and Aspect" 228). To recall Foucault's thesis, within one and the same modern juridical frame, the capillary mechanisms of counter-law disqualify and invalidate the egalitarian law by turning it into a discriminatory inquisitorial machine (Foucault 222-227). Under such continuously exceptional circumstances, Kafka's narrative authority takes the shape of an elusive "imaginary norm" whose application is in the hands of its addressees, with all the risk of subversive invention that this implies. His technique of authoring exposes his readers to the same fictional law

${ }^{7}$ The phrase is borrowed from Coetzee's heroine Elizabeth Costello, who herself borrows it from Czesław Milosz. According to her explanation, she is only one of "the many secretaries over the ages" (Elizabeth Costello 199). As one of his interpreters (Marais passim) puts it, Coetzee himself receives his authorial vocation from an invisible otherness, which is why he also acts as "the secretary of the invisible."

${ }^{8}$ Muirs translate the German title "Der Bau" as "The Burrow," repeatedly sacrificing the key concept of construction. 
that he as the author was exposed to by the whimsical lawgivers of his time. It is up to them to explore its limitless possibilities as he himself has done, via his numerous doppelgangers, with the inaccessible law that he was dependent upon.

\section{WORKS CITED}

Agamben, Giorgio. State of Exception. Trans. Kevin Attell. Chicago: The University of Chicago Press, 2005.

Anderson, Benedict. Imagined Communities: Reflections on the Origin and Spread of Nationalism. Rev. and ext. edition. London: Verso, 1991.

Bergengruen, Maximilian. "Vordem Gesetzsind alle Staatsbürger gleich?: Rechtsgrundsatz und Gesetzesfiktion in Kafkas Türhüter-Legende." Deutsche Vierteljahrschrift für Literaturwissenschaft und Geistesgeschichte 90.3 (2016): 415-434.

Coetzee, John Maxwell. “Time, Tense, and Aspect in Kafka's 'The Burrow." Doubling the Point: Essays and Interviews, Cambridge, MA; London: Harvard University Press, 1992. 210-232.

Coetzee, John Maxwell. Disgrace. London: Secker \& Warburg, 1999.

Coetzee, John Maxwell. Elizabeth Costello. London: Vintage, 2004.

Cohen, Gary B. "Our Laws, Our Taxes, and Our Administration: Citizenship in Imperial Austria." Shatterzone of Empires: Coexistence and Violence in the German, Habsburg, Russian and Ottoman Borderlands. Eds. Omer Bartov and Eric D. Weitz. Indiana University Press: Bloomington and Indianapolis, 2013. 103-121.

Foucault, Michel. Discipline and Punish: The Birth of the Prison. Trans. Alan Sheridan. New York: Vintage, 1977.

Friedman, Lawrence M. "Lexitainment: Legal Process as Theater." DePaul Law Review 50.2 (2000): 539-558.

Hegel, Georg Wilhelm Friedrich. Aesthetics: Lectures on Fine Art. 1. Trans. T. M. Knox. Oxford University Press: Oxford, 1975.

Judson, Pieter. The Habsburg Empire: A New History. Cambridge, MA; London: The Belknap Press of Harvard University Press, 2016.

Kafka, Franz. "Beim Bau der chinesischen Mauer." Beim Bau der chinesischen Mauer und andere Schriften aus dem Nachlass. Gesammelte Werke in zwölf Bänden. 6. Ed. Hans-Gerd Koch. Frankfurt am Main: Fischer Taschenbuch Verlag, 1994. 65-80.

Kafka, Franz. Briefe 1902-1924. Ed. Max Brod. Frankfurt am Main: Fischer, 1966.

Kafka, Franz. Der Proceß. In der Fassung der Handschrift. Gesammelte Werke in zwölf Bänden. 3. Ed. Hans-Gerd Koch. Frankfurt am Main: Fischer, 1994.

Kafka, Franz. Diaries 1910-1923. Trans. J. Kresh and M. Greenberg. New York City: Schocken Books, 1988.

Kafka, Franz. "The Great Wall of China." The Complete Stories. Trans. W. and E. Muir. New York: Schocken Books, 1988. 266-279.

Kafka, Franz. "The Problem of Our Laws." The Complete Stories. Trans. W. and E. Muir. New York: Schocken Books, 1988. 482-483.

Kafka, Franz. "The Refusal." The Complete Stories. Trans. W. and E. Muir. New York: Schocken Books, 1988. 295-300.

Marais, Mike. The Secretary of the Invisible: The Idea of Hospitality in the Fiction of J. M. Coetzee. Amsterdam and New York: Rodopi, 2009. 
Schmitt, Carl. Political Theology. Trans. George Schwab. Cambridge: MIT Press, 1985. Slaughter, Joseph R. Human Rights, Inc. New York: Fordham University Press, 2007. Stourzh, Gerald. "Ethnic Attribution in Late Imperial Austria: Good Intentions, Evil Consequences." The Habsburg Legacy: National Identity in Historical Perspective. Eds. Ritchie Robertson and Edward Timms. Edinburgh: Edinburgh University Press, 1994. 67-83.

Wetzell, Richard F. Inventing the Criminal. Chapel Hill: University of North Carolina Press, 2000.

Wittgenstein, Ludwig. Notebooks 1914-1916. Eds. G. H. von Wright and G. E. M. Anscombe. Chicago: University of Chicago Press, 1980.

Ziolkowski, Theodore. The Mirror of Justice: Literary Reflections of Moral Crisis. Princeton and Oxford: Princeton University Press, 1997.

\section{Izjemno stanje: rojstni kraj Kafkove pripovedne avtoritete}

Ključne besede: Avstro-Ogrska / srednjeevropska književnost / literarna periferija / Kafka, Franz / literarni liki / obstranci / subverzivnost

$\mathrm{V}$ postimperialni vzhodni in srednji Evropi, v kateri se je geopolitični prostor preoblikoval po vzoru zahodnoevropskih nacionalnih držav, so se širili nepredelani človeški preostanki kot stranski učinki politično vodene nacionalne homogenizacije. Ti položajni obstranci, ki jim ni bilo dovoljeno, da bi postali berljivi v okviru na novo vzpostavljenih političnih prostorov, zavzamejo osrednje prizorišče Kafkovih pripovedi ne le kot literarni liki, temveč tudi kot pripovedovalci in vrhovna avtoriteta. Strastno se navežejo na cone nerazločnosti, na katere jih je obsodila »egalitarna diskriminacija« modernih družb, s čimer skušajo svojo politično razlaščenost spremeniti v literarno prednost. Dokazoval bom, da Kafkove pripovedi dolgujejo svojo izmuzljivo vrhovno avtoriteto prav tej nenehni transformaciji političnega izjemnega stanja svojih akterjev v njihovo literarno samoizvzetje. Čeprav si akterji nenehno prizadevajo za preobrazbo vsiljenega izjemnega stanja skozi to nenavadno literarno prilastitev, ostaja Kafkova pripovedna avtoriteta za korak v prednosti. Kafkov postkolonialni naslednik J. M. Coetzee je najbolj občudoval prav to njegovo neskončno gradacijo subverzivne mimikrije.

1.01 Izvirni znanstveni članek / Original scientific article

UDK 821.112.2.09(436)Kafka F.

DOI: https://doi.org/10.3986/pkn.v43.i1.06 